\section{REFERENCES}

1. Czekierda, P. i in. (red.) (2009). Tutoring w szkolemiędzy teoria a praktyka zmiany edukacyjnej [Tutoring at school - between theory and the practice of educational change]. Wrocław: Towarzystwo Edukacji Otwartej. [in Polish].

2. Fijałkowski, A. (2009). Z dziejów myśli o tutoringukrótki zarys historii indywidualnego ksztatcenia $i$ wychowania [From the history of thinking about tutoring - a brief outline of the history of individual education and upbringing]. Kwartalnik Pedagogiczny, no. 2, pp.5-34. [in Polish].

3. Fundacja Kolegium Tutorów [The Tutor Collegium Foundation]. Available at: http://tutoring.pl. [in Polish].

4. Kosno, M. (2013). Kompetentny tutor. Znaczenie funkcji zarzadzajacych dla przebiegu tutoringu rówieśniczego [Competent tutor. The importance of management functions for the course of peer tutoring]. Psychologia Rozwojowa, 18, no. 4, pp.95-110. [in Polish]

5. Osadcha, K. (2017). Spetsyfika orhanizatsii tiutorskoho suprovodu uchniv pochatkovoi shkoly [The specific of organization of the tutors support of students of primary school]. Yoth \& market, vol. 5(148), pp. 63-69. [in Ukrainian].

6. O projekcie [About the project]. Available at: http:// sp48gdy.webd.pl/do wymiany/Tutoring/index.html. [in Polish].

7. PROGRAM Akredytowany Praktyk Tutoringu ścieżka po PT. [PROGRAM Accredited Tutoring Practice - path after PT]. Available at: http://www.tutoring.edu.pl/ program-akredytowany-praktyk-tutoringu-sciezka-popt,47. [in Polish].

8. PROGRAM Akredytowany Praktyk Tutoringu ścieżka po ST. [PROGRAM Accredited Tutoring Practice - path after ST]. Available at: http://www.tutoring.edu.pl/ program-akredytowany-praktyk-tutoringu-sciezka-post,46. [in Polish].

9. Sarnat-Ciastko, A. (2010). Tutor a wychowawca. Rzeczywistość nadana czy wybrana [Tutor and educator. The reality given or chosen]. Podstawy Edukacji, 3, pp.7688. [in Polish].

10. Szkoła Tutorów. Available at: http://cw.edu.pl/ program/szkola-tutorow. [in Polish].

Стаття надійшла до редакції 28.05.2018

УДК 7.03(477)

DOI:

Оксана Петрів, кандидат філософських наук, дочент кафедри культурології та мистецьької освіти Дрогобицького державного педагогічного університету імені Івана Франка

\title{
ЕТНОКУЛЬТУРНИЙ ВИМІР УКРАЇНСЬКОЇ ХУДОЖНЬОЇ КУЛЬТУРИ ПОЧАТКУ 20 СТ.
}

У статтірозглянутоособливостіукраїнськоїхудожньоїкультурипочатку $20 \mathrm{~cm}$., якарозвивалася уруслінаміонального відродження $і$ збережкення етнічної самобутності та ідентичності в умовах радянської тоталітарної держсави. Показано культурно-мистечьку ситуацию початку 20 ст., вказано на вияв активної національної свідомості української творчої еліти. Обтрунтовано, що украӥнська культура початку $20 \mathrm{~cm}$. характеризується відродженням національних ицінностей, етнічних традииій, зростаннямнаиіональної свідомості тавідображенням етнічної самобутності ухудожсній культурі.

Ключові слова: художня культура; мистеитво; етнічна культура; національне відродження; начіональна свідомість; етнічна самобутність.

Jim. 11.

Oksana Petriv, Ph.D. (Philosophy), Associate Professor of the Cultural Studies and Artistic Education Department

Drohobych Ivan Franko State Pedagogical University

\section{ETHNOCULTURAL DIMENSION OF UKRAINIANARTISTIC CULTURE AT THE BEGINNING OFTHE 20TH CENTURY}

The article considers the special features of the Ukrainian artistic culture of the early 20th century, which developed in line with the national revival and the preservation of ethnic selfhood and identity in the conditions of the Soviet totalitarian state. It shows the cultural and artistic situation at the beginning of the 20th century and indicates the expression of active national consciousness of the Ukrainian creative elite. The research substantiates that the Ukrainian culture of the early 20th century was characterized by the revival of national values, ethnic traditions, the growth of national consciousness and the reflection of ethnic identity in artistic culture. It has been revealed that the Ukrainian art of this age largely reflected the complexity, ambiguity and peculiarity of the political, national and cultural situation in Ukraine. The development of the Ukrainian art of the 1920s and 1930s went beyond purely artistic problems, hence it was closely linked to the prospect of the national and cultural development. The emergence of the outlook of artists of this age was influenced by the sources of ethnic culture (folk art, Ukrainian icon painting, ornamentation), which determined the originality and national specificity of their works. Beginning in 1933, the communist government was severely controlling the ideological situation in the country, cultural 
processes were unified with the help of the method of "socialist realism", which foresaw a mandatory eulogy of the achievements of socialism. The national and cultural revival in Ukraine of the 1920s and 1930s was brutally destroyed by totalitarian power and entered history as "Shot Revival".

Keywords: an artistic culture; art; an ethnic culture; national revival; national consciousness; ethnic identity.

П остановка проблеми. В умовах глобалізації та полікультурності сучасного світу актуалізується проблема збереження національної ідентичності української культури та художньої культури зокрема. Українська культура початку 20 ст. характеризується відродженням національних цінностей, етнічних традицій, зростанням національної свідомості та відображенням етнічної самобутності у художній культурі. У всі часи мистецтво було тією сферою, яка активно впливала на свідомість людини і таким чином на формування ії світогляду. Мистецтво художніми засобами створює нову дійсність, включаючи певні ідейні сенси творців у мистецькі твори, споживання яких має сугестивний вплив на реципієнта. Таким чином, мистецтво - це цілий окремий світ, який існує паралельно з реальним, i має сугестивний вплив на нього. Філософ Карл Ясперс стверджував, що мистецтво "у всі часи $€$ чимось куди більшим, аніж естетичним, воно вміщує і несе в собі усяке духовне, ідейне, релігійне" $[11,75]$. Мистецтво як духовна форма організації бугтя впливає на організацію людського буття, надаючи йому естетичної, а іноді й ідеологічної визначеності. Особливістю мистецтва $€$ можливість створення нової реальності - такої реальності, яка відображає не реальний світ, а бажаний. "Мистецтво не має права на існування, якщо обмежується

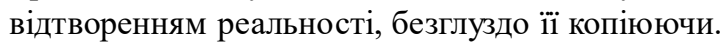
Його місія - створювати уявні світи" [7, 268], вважав Х. Ортега-і-Гассет. Мистецтво дає нам образ конкретної суб'єктивної реальності, яка здатна викликати емоції, рефлексію, емпатію, сугестію. Явище сугестії пов'язане з актом навіювання, впливом на психіку реципієнта мистецького твору, в якому автор втілив певну ідею. Яскравим прикладом використання мистецтва для служіння державі в умовах радянської дійсності є 1920 - 1930 роки, коли насаджувався ідеологічний монополізм у всіх сферах культури, а діяльність митців стала настільки регламентованою, що втрачала ознаки творчості. Цей період в історії української культури отримав назву "Розстріляне Відродження". Термін "Розстріляне Відродження" вперше вжив польський публіцист і громадський діяч Сжи Гедройць, запропонувавши назвати так антологію української літератури 1917 - 1933 рр., підготовлену Юрієм Лавріненком у листі до останнього. Антологія “Розстріляне Відродження”, яка з'явилася коштом Сжи Гедройця 1959 р., включає художні твори видатних українських письменників і поетів та $\epsilon$ свідченням значного розвитку української духовної культури цієї доби.

Аналіз останніх досліджень і публікацій. Проблема відображення етнокультурної самобутності в художній культурі досліджується багатьма науковцями. Окремі аспекти цієі проблеми висвітлюють у своїх наукових розвідках учені А. Бичко, Є. Блакитний, Л. Госейко, О. Забужко, М. Кушнір, Ю. Лавріненко, М. Наєнко, М. Попович, О. Потебня, В. Січинський, І. Франко. Мистецтвознавець Євген Блакитний у статті "Національне та інтернаціональне в мистецтві", аналізуючи вершинні здобутки світового мистецтва, вказує на досягнення українських митців початку 20 ст., що "вийшли 3 надр українського народу”, однак “московський режим" "нещадно розправився 3 новим мистецьким рухом" $[1,151]$. Історик мистецтва Володимир Січинський у статті “Стиль в українському мистецтві” досліджує питання українського стилю у мистецтві, наголошує на його відмінності і самобутності, стверджує, що коли "існує народ, то існує і його мистецтво", зазначає, що національні особливості виявляються не тільки у змісті твору, а й у формі $[9,416]$. Катерина Варшавська у статті "Юхим Михайлів. Митець і його час" обгрунтовує вплив етнічної культури та українського народного мистецтва зокрема на формування національної свідомості художника Юхима Михайліва та його творчість [2].

Мета статті - визначення етнокультурних аспектів української художньої культури початку 20 ст.

Виклад основного матеріалу. Аналізуючи художню культуру 1920 - 1930-х років, варто вказати на її художню та ідейну оригінальність та виразну спрямованість на світогляднофілософську тематику та інтерес до етнічнофілософських проблем. Таке поєднання створювало особливу культурну атмосферу, в якій творча інтелігенція реалізовувала культурний феномен українського відродження. "Те, що виношувалось народом століттями, мусило за сприятливих обставин знайти свій вияв назовні. Такими сприятливими обставинами були передреволюційні та революційні роки, коли українська духовність на короткий час здобувши 


\section{ЕТНОКУЛЬТУРНИЙ ВИМІР УКРАЇНСЬКОЇ ХУДОЖНЬОЇ КУЛЬТУРИПОЧАТКУ 20 СТ.}

свободу, могла себе проявити в усю свою широчінь і в усій своїй повноті й глибині", зазначає мистецтвознавець Свген Блакитний [1, 151]. Мистецтво тоді є цікавим, неповторним, цінним, коли відображає самобутність народу. Хоча комуністична ідеологія намагалася відокремити етнічні культури від етнонаціонального простору, замінити національні цінності універсальними загальнолюдськими, етнічні чинники проявлялися в усіх сферах культури, насамперед у мистецькій діяльності. Поштовх до яскравого вияву етнічного макросвіту часто виникає саме в умовах загрози буттю певної етнічної культури. Творчість діячів цього відродження Миколи Хвильового, Валер'яна Підмогильного, Миколи Куліша, Свгена Плужника, Миколи Вороного, Миколи Зерова, Михайла Ялового, Олеся Досвітнього, Григорія Косинки, Михайла Драй-Хмари, Дмитра Фальківського та багатьох інших була намаганням зберегти i творчо розвинути українську національну культуру 3 притаманною їй неповторною ментальністю українського народу, водночас їхня творча діяльність не була опозиційною до радянської влади. Радянський Союз як поліетнічна імперія декларував свободу, незалежність, рівні права та можливості для всіх націй і народностей, тому передова інтелігенція мала сподівання на збереження етнічної самобутності та всебічний культурнонаціональний розвиток на засадах принципів рівності і справедливості, тому багато представників творчої інтелігенції були навіть членами КП(б)У.

Визначальною особливістю українського образотворчого мистецтва початку 20 ст. $є$ утвердження національної самобутності у поєднанні зі світовим мистецьким досвідом. У пошуках нової духовності українські митці шукали засобів оновлення мистецтва. Зокрема вони намагалися віднайти джерела відновлення сакрального сенсу мистецтва утрадиціях етнічної культури. Митці заглиблювалися в історичні корені, шукаючи джерела інтуїтивної, ірраціональної, алегорично-символічної природи художньої творчості. Творчі експерименти митців сприяли формуванню нової художньої свідомості, для якої характерне подолання нормативності, перенесення акценту з предметів навколишньої дійсності на внутрішній світ людини, їі ідеальнодуховне буття. Митці прагнули відображати внутрішній світ людини у її складних i багатогранних зв'язках з навколишнім світом. Вони намагалися переорієнтувати статус мистецтва у суспільній свідомості від споживацького рівня до буттєво-світоглядного. На становлення світогляду митців цієї доби вплинули джерела національної культури (народна творчість, український іконопис, орнаментика), що зумовило самобутність і національну специфіку ïх творчості. Джерела творчості митці шукали в особистісному самозаглибленні й самопізнанні. Новаторські пошуки властиві творчості таких видатних митців цієї доби, як Петро Холодний, Юхим Михайлів, Олекса Новаківський, Анатоль Петрицький, Казимир Малевич, Олександр Архипенко, Олександра Екстер, Олександр Богомазов, Віктор Пальмов, Михайло Бойчук, Іван Падалка, Василь Седляр.

Михайло Бойчук започаткував новий напрям монументального мистецтва 20 ст., базований на поєднанні українських традицій і європейських здобутків. За основу свого художнього методу митець взяв принцип органічного синтезу досягнень світової мистецької спадщини, зокрема візантійського мистецтва, народних традицій і нових форм, які відповідали б національним особливостям. На думку М. Бойчука, в пошуках нових шляхів у мистецтві слід відшукати досконалі твори в художній спадщині всіх епох і всіх народів, запозичити та переосмислити сутнісне. Ідеологічна програма АРМУ (Асоціації революційних митців України, ) - творчого об'єднання українських радянських художників (1925 - 1932), основу якої становили бойчукісти, починалася 3 заклику боротися за якість твору мистецтва, за нову форму в мистецтві. В історію національної культури увійшов термін “бойчукізм” - назва самобутньої школи Михайла Бойчука, метою творчості якої була організація життєвого середовища людини, концепція створення національного мистецтва. Бойчукісти вірили у значну роль монументального мистецтва у формуванні середовища, його вплив на світосприйняття людини. Михайло Бойчук пов' язував свою діяльність із мрією про культурне відродження України, він був апологетом високого мистецтва, вважаючи його вершиною творчості, і пов'язував елітарне мистецтво з народними джерелами. На думку художника, будь-яке значне мистецьке досягнення можливе лише на основі досягнень минулого. Твори бойчукістів базувалися на народному мистецтві, чим відроджували та утверджували національну свідомість, об'єднуючи народ, що зрештою стало причиною розправи радянської влади над митцями. Бойчукізм вплинув на розвиток живопису, скульптури, мистецтва фрески, графіки, кераміки, різьблення, ткацтва, килимарства. Монументальне мистецтво Михайла Бойчука та 
його школи є великим надбанням української культури 20 ст.

Значні творчі здобутки має також українська графіка початку 20 ст. Започаткували стильові ознаки українського мистецтва 20 - 30-х рр. 20 ст. у графіці такі видатні митці, як Георгій Нарбут, Василь Кричевський, Тимофій і Михайло Бойчуки, Іван Падалка, Василь Седляр, Олена Кульчицька, Антон Середа, Олекса Новаківський, Петро Холодний. Георгій Нарбут є автором “Української абетки”, перших українських державних знаків (банкнот і поштових марок), оформлювачем банкнот української гривні доби УНР. Георгій Нарбут формував основу національного мистецтва, нову, відповідну часові художню мову, базовану на традиціях українського, а також візантійського і барокового мистецтва. Орнаменти давніх вишивок, писанок, різьблення Г. Нарбут переосмислював і надавав їм сучасного вияву.

Юхим Михайлів - видатний український живописець, поет, мистецтвознавець, непересічний художник-символіст, графік, талановитий оформлювач книжок, автор численних ілюстрацій, обкладинок часописів, афіш; він був настільки свідомий патріот української культури, що не написав жодної картини, яка б славила радянську дійсність. Картини 3 українською тематикою $\epsilon$ найважливішими у його творчості, серед найзнаковіших - “Загублена воля” (1916), “Соната України” (1916), “Музика зір” (1919), “Руїни слави” (1920), “Загублена булава” (1922), “Чайка” (1930), "Гетьманський намет” (1930). Кожна картина має глибинно-змістовні образи, які виявляють любов до народної традиції і славлять минуле. “Юхим Михайлів належить до тієї плеяди талановитих українських митців, з якою цілком справедливо пов'язують стрімкий злет українського мистецтва у 1920 - 1930-х роках", стверджує Катерина Варшавська [2, 1141]. На початку мистецького життя художник працював у музеї старожитностей імені Олександра Поля в Катеринославі (сьогодні місто Дніпро), де збирав взірці народного мистецтва, мав можливість спілкуватися 3 селянами, малював для етнографічного відділу. Директором музею був Дмитро Яворницький, який “розкрив молодому співробітникові таємницю українського духу” [2, 1139]. "Праця та спілкування з Яворницьким стали справжньою школою виховання й гартування національної свідомості художника, саме за його порадою Михайлів розпочав досліджувати проблеми становлення і розвитку українського народного мистецтва. За дорученням музею
Михайлів збирав в околишніх селах взірці народного орнаменту, змальовуючи візерунки 3 пічок, стін та вікон”, - зазначає Катерина Варшавська $[2,1139]$. Цей досвід збагатив його знання про народне мистецтво та традиції, поглибив його любов до України, що відобразилося у мистецькій творчості художника та вплинуло на iii самобутність. Юхим Михайлів вів активну мистецтвознавчу діяльність, писав наукові та популярні статті на різні теми з української культури, написав статті про творчість художників Георгія Нарбута, Михайла Жука, Леоніда Позена, Олександра Мурашка тощо, видав книгу “Гончарна кераміка на Україні” (1921). Його любов і повага до української традиції та захоплення українським народним мистецтвом зробили художника “політично ненадійним” в тоталітарній державі. 1934 року Юхим Михайлів був безпідставно звинувачений у підготовці збройного повстання, заарештований i відправлений у заслання у місто Котлас (Архангельська обл.). Там художник продовжував малювати, писати вірші, мріяв про повернення додому, однак 1935 р. його життя обірвалося.

Основою світогляду новітньої мистецької еліти були любов до рідної землі і країни, свобода мислення та щира віра у власні ідеали, що і виявлялося у їхніх творах. Етнічне існує завжди, у несприятливих умовах воно існує у прихованих формах і впливає на особливості культури. Етнокультура є джерелом і основою буття етносу. “Етнокультура - культура, першоджерелом якої $є$ колективна творчість даної спільноти, що включає спосіб життя, світогляд, мову, народне мистецтво" $[5,208]$. Українські митці, виявляючи і отже зберігаючи власну етнічну ідентичність, у цей складний час своєю творчістю, за словами М. Наєнка, “відвертали культурну смерть України” [6, 3]. На думку М. Бердяєва “без первинної та стихійної любові до своєї країни неможливий ніякий творчий історичний шлях... Народ повинен бути, повинен берегти свій образ, повинен розвивати свою енергію, повинен мати можливість творити свої цінності" [8, 67]. Етнокультура у процесі життєдіяльності етносу збагачується, удосконалюється, таким чином зазнаючи певних змін, однак залишається самодостатньою і є засобом самозбереження етносу. Важливою особливістю етнокультури є етнічна самоідентифікація, тобто ототожнення себе $з$ певною етнічною спільнотою, належність до неї, що зрештою виявляється у життєдіяльності кожної людини, особливо це стосується творчої діяльності. “Все-таки ядро 
справді українського мистецтва спочиває на плечах тих митців, які свідомо шукають українського виразу, українського стилю та в усякому разі перетворюють модерні течії в горнилі національної творчості", - стверджує історик мистецтва Володимир Січинський $[9,185]$.

1920 - 1930 роки стали періодом активного розвитку у сфері української художньої культури, часом утвердження етнічної самобутності, національного самоствердження, яке набувало рис “відродження”. У цей час комуністична партія ще не підпорядкувала собі усі сфери життєдіяльності. Політичні зміни наповнили культурну діяльність творчих людей відчуттям свободи, новизни, нових можливостей, звільнення від цензурних обмежень. У квітні 1923 року радянська влада оголосила офіційним курсом партії коренізацію, в Україні ця програма отримала назву “українізації”: було прийнято рішення про українізацію усіх державних сфер, усі робітники і службовці були зобов'язані вивчити українську мову. Коренізація була запроваджена радянською владою 3 метою розширення свого впливу на місцеве населення. Однак уже у квітні 1927 р. постанова комуністичної партії визнавала “особливе значення російської мови” на всій території Радянського Союзу. 3 того часу почалося активне протистояння українізації з боку влади. Однак поширення навіть на короткий час україномовної освіти створило підгрунтя для розвитку української культури, мистецтва зокрема. Ця короткочасна політика коренізації сприяла значному розвиткові етнічної культури та окрилила українських митців на вільну творчу діяльність і максимальне розкриття своїх творчих можливостей. За твердженням Ентоні Сміта, етнічне відродження - це спроба зберегти минуле і водночас трансформувати його в дещо нове, побудувати новий тип життя на стародавніх підвалинах, створити нову людину і нове суспільство через відродження старої ідентичності..." [3, 474].

Українська творча інтелігенція цієї епохи у своїй діяльності виходила далеко за межі суто художніх проблем, митці намагалися визначити перспективи національно-культурного розвитку. Декларована радянською владою “українізація" спричинила створення чисельних мистецьких угрупувань, були створені літературні об'єднання “Ланка" (згодом - “МАРС”), “Плуг”, “Спілка письменників Західної України”, "Гарт” (згодом був перейменований на “ВАПЛІТЕ” (Вільна академія пролетарської літератури), “Молодняк” (неокласики), ЛОЧАФ (об’ єднання армії і флоту); мистецькі об’єднання “Асоціація революційного мистецтва України” (АРМУ), “Об’єднання мистецької молоді України”, “Об’єднання сучасних митців України”, “Асоціація художників Червоної України”, “Українське мистецьке об'єднання”. Письменник Микола Хвильовий започаткував літературну дискусію 1925 1928 рр. про шляхи розвитку української літератури, митець закликав орієнтуватися на кращі взірці світового письменства, тобто на європейську культуру та їі гуманістичні традиції, а не на радянську Росію, відмовитися від провінціалізму та примітиву в літературі; письменник висунув гасло “Геть від Москви!", маючи на увазі необхідність культурної переорієнтації на "психологічну Європу". Творчість М. Хвильового спочатку виявляла віру письменника у світлі ідеали революції, а згодом - розчарування і скепсис щодо їх здійснення. У своій публіцистичній праці “Апологети писаризму” М. Хвильовий радив українським митцям орієнтуватися на європейські цінності: "Від російської літератури, від іiі стилів українська поезія мусить якомога швидше втікати... Наша орієнтація - на західноєвропейське мистецтво, на його стиль, на його прийоми" [10,573]. М. Хвильовий та його однодумці намагалися розв'язати тодішні актуальні культурні проблеми України на засадах націонал-комунізму, тому літературна дискусія 1925 - 1928 років в умовах тоталітарного режиму в СРСР була приречена на знищення, а ііі учасники стали жертвами офіційної нищівної критики і політичного гоніння. Комуністична партія СРСР почала діяти жорстокими методами: репресіями, арештами, розстрілами. У 1933 р. репресії проти української інтелігенції посилилися, було розпочато наступ на українську культуру. Початком масового нищення української інтелігенції вважається травень 1933 року, коли 12 - 13 числа відбувся арешт Михайла Ялового і самогубство Миколи Хвильового. Митці опинилися перед вибором: писання творів на уславлення партії, соціалістичної дійсності у дусі соціалістичного реалізму, мовчання або репресії і концтабори. Кульмінацією дій тоталітарного режиму стало 3 листопада 1937 року, коли у Соловецькому таборі було розстріляно понад сто осіб представників української інтелігенції. Серед знищених були: Лесь Курбас, Микола Куліш, Павло Филипович, Мирослав Ірчан, Олекса Слісаренко, Матвій Яворський... Точні дані щодо кількості репресованих українських митців залишаються невстановленими. Знищені українські інтелектуали та втрачені духовні мистецькі цінності цієї доби значно збіднили духовний потенціал України та унеможливили 


\section{ЕТНОКУЛЬТУРНИЙ ВИМІР УКРАЇНСЬКОЇ ХУДОЖНЬОЇ КУЛЬТУРИПОЧАТКУ 20 СТ.}

повноцінний розвиток української культури. Багато імен митців цього періоду ще залишаються маловідомими, а їхня творчість є забутою. Значна кількість мистецьких творів цих митців була знищена, частина залишається у приватних

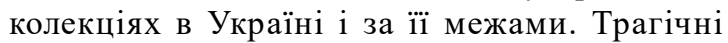
наслідки знищення творців художньої культури покоління "Розстріляного Відродження" відчуваємо й сьогодні.

Висновки. Отже, культурно-мистецька ситуація 1920 - 1930-х років засвідчила значний вияв активної національної свідомості української творчої еліти. Вітчизняна художня культура початку 20 ст. розвивалася у руслі національного відродження і збереження етнічної самобутності та ідентичності в умовах радянської тоталітарної держави. Українське мистецтво цієї доби значною мірою віддзеркалило складність, неоднозначність і своєрідність політичної та національно-культурної ситуації в Україні. Розвиток українського мистецтва початку 20 ст. виходив за межі суто художніх проблем, а був тісно пов'язаний 3 перспективою національно-культурного розвитку. У цей період відбувалося утвердження ідеї національного відродження, посилення національно-етнічних начал у творчій діяльності та освоєння і розвиток найновіших здобутків західноєвропейського мистецтва. На становлення світогляду митців цієї доби вплинули джерела національної культури (народна творчість, український іконопис, орнаментика), що зумовило самобутність і національну специфіку їх творчості. Починаючи з 1933 року комуністична влада взяла під жорсткий контроль ідеологічну ситуацію в країні, культурні процеси уніфікувалися за допомогою методу “соціалістичного реалізму”, який передбачав обов'язкове оспівування досягнень соціалізму. Національно-культурне відродження в Україні 1920 - 1930-х років було жорстоко знищене тоталітарною владою і увійшло в історію як "Розстріляне Відродження".

\section{ЛІТЕРАТУРА}

1. Блакитний $€$. Національне та інтернаціональне в мистецтві / С. Блакитний // Хроніка 2000: Український культурологічний альманах. Випуск $39-40 .-$ К.: Фонд сприяння розвитку мистецтв, 2000 . -800 с. - С. $142-$ 151.

2. Варшавська К. Юхим Михайлів. Митець і його час (за матеріалами збірок музейних фондів Українського Культурно-Освітнього центру Бавнд Брука, Нью Джерсі, США) / К. Варшавська // Народознавчі зошити. - 2013. - № 6 (114). - С. 1138 1144.

3. Картунов О. Етнічний ренесанс (сутність i характер) / О. Картунов // Мала енциклопедія етнодержавознавства / НАН України. Ін-т держави і права ім. В.М. Корецького; редкол.: Ю.І.Римаренко (відп. ред.) та ін. -К.:Генеза, 1996. - 942 с. - С. $473-474$.

4. Кушнір М. Велич мистецтва і відродження культури / Кушнір М. // Хроніка 2000: Український культурологічний альманах. Випуск $39-40$. - К.: Фонд сприяння розвитку мистецтв, 2000. - 800 с. - С. 188 208.

5. Лісовий В. Етнокультура / В. Лісовий // Філософський енциклопедичний словник. -К.: Абрис, 2002. -744 c. - C. 208.

6. Наєнко М. Відвернули культурну смерть України / М. Наєнко // Лавріненко Ю.А. Розстріляне відродження: антологія 1917 - 1933: поезія - проза драма - есей / підгот. тексту, фахове редагування і передм. проф. Наєнка М.К. - К.: Вид. центр "Просвіта", 2001. -794 c. - C. $3-12$.

7. Ортега-і-Гассет X. Дегуманізація мистецтва / Х. Ортега-і-Гассет // Ортега-і-Гассет Х. Вибрані твори / пер. 3 ісп. В. Бурггардта, В. Сахна, О. Товстенко. - К.: Основи, 1994. -420 с. - С. $238-272$.

8. Римаренко Ю. Етнонаціональне буття / Ю. Римаренко// Мала енциклопедія етнодержавознавства / НАН України. Ін-т держави і права ім. В.М. Корецького; редкол.: Ю.І.Римаренко (відп. ред.) та ін. - К.: Генеза, 1996. -942 c. - С. $67-68$.

9. Січинський В. Стиль в українському мистецтві / Січинський В. // Хроніка 2000: Український культурологічний альманах. Випуск $39-40 .-$ К.: Фонд сприяння розвитку мистецтв, 2000 . -800 с. - С. 182 187.

10. Хвильовий М. Апологети писаризму/ М. Хвильовий // Хвильовий М. Твори: У 2 т. К.: Дніпро, 1990. - T. 2. -925 c. - C. $515-575$.

11. Ясперс К. Психологія світоглядів / К. Ясперс / 3 нім пер. О.Кислюк, Р.Осадчук. - К.: Юніверс, 2009. $464 \mathrm{c}$.

\section{REFERENCES}

1. Blakytnyi, Ye. (2000). Natsionalne ta internatsionalne $\mathrm{v}$ mystetstvi [National and international aspects in art]. Khronika 2000: Ukrainskyi kulturolohichnyi almanakh. Vol. 39 - 40, Kyiv: Fond spryiannia rozvytku mystetstv, 800 p, pp. 142 - 151.[in Ukrainian].

2. Varshavska, K. (2013). Yukhym Mykhailiv. Mytets $i$ yoho chas (za materialamy zbirok muzeinykh fondiv Ukrainskoho Kulturno-Osvitnoho tsentru Bavnd Bruka, Niu Dzhersi, SShA)[The artist and his time (based on the materials of the collections of the museum funds at the Ukrainian Cultural and Educational Centre, Bound Brook, NJ, USA)]. Narodoznavchi zoshyty. No.6(114), pp. 1138 1144. [in Ukrainian].

3. Kartunov, O. (1996). Etnichnyi renesans (sutnist i kharakter) [Ethnic Renaissance (essence and character)]. Mala entsyklopediia etnoderzhavoznavstva. NAN Ukrainy. In-t derzhavy i prava im. V.M. Koretskoho;(Ed.). Yu. I. Rymarenko. Kyiv: Heneza, 942 p, pp. 473 - 474.[in Ukrainian].

4. Kushnir, M. (2000). Velych mystetstva i vidrodzhennia kultury [The greatness of art and the revival of culture]. Khronika 2000: Ukrainskyi kulturolohichnyi 


\section{ХРИСТИЯНСЫКАПЕДАГОГІКА ВИХОВАННЯ ДІТЕЙ ТА МОЛОД У ПРОСВІТНИЦЫКІЙ ДІЯЛЬНОСТІ АНДРЕЯ ШЕПТИЦЫКОГО}

almanakh. Vol. 39 - 40, Kyiv: Fond spryiannia rozvytku mystetstv, 800 p, pp. 188 -208.[in Ukrainian].

5. Lisovyi, V. (2002). Etnokultura [Ethnoculture]. Filosofskyi entsyklopedychnyi slovnyk. Kyiv: Abrys, 744 p, p. 208. [in Ukrainian].

6. Naienko, M. \& Lavrinenko, Yu.A. (2001). Vidvernuly kulturnu smert Ukrainy [The cultural death of Ukraine has been averted]. Rozstriliane vidrodzhennia: antolohiia 1917 - 1933: poeziia - proza - drama - esei. Pidhot. tekstu, fakhove redahuvannia i peredm. prof. Naienka M.K. Kyiv: Vyd. tsentr "Prosvita", 794 p, pp. 3 - 12. [in Ukrainian].

7. Ortega-i-Gasse, Kh. (1994). Dehumanizatsiia mystetstva [Dehumanization of art]. Kyiv: Osnovy, $420 \mathrm{p}$ pp. $238-272$. [in Ukrainian].
8. Rymarenko, Yu. (1996). Etnonatsionalne buttia [Ethnonational being]. Mala entsyklopediia etnoderzhavoznavstva. NAN Ukrainy. In-t derzhavy $i$ prava im. V.M. Koretskoho; (Ed.).Yu.I.Rymarenko et al., Kyiv: Heneza, 942 p, pp. 67 - 68. [in Ukrainian].

9. Sichynskyi, V. (2000). Styl v ukrainskomu mystetstvi [Style in the Ukrainian art]. Khronika 2000: Ukrainskyi kulturolohichnyi almanakh. Vol. 39 - 40, Kyiv: Fond spryiannia rozvytku mystetstv, 800 p, pp. $182-187$. [in Ukrainian].

10. Khvylovyi, M. (1990). Apolohety pysaryzmu [Apologists of "pysarysm"]. Kyiv: Dnipro, vol. 2, 925 p, pp. 515-575. [in Ukrainian].

11. Yaspers, K. (2009). Psykholohiia svitohliadiv [Psychology of worldviews]. Kyiv: Yunivers, 464 p. [in Ukrainian].

Стаття надійшла до редакції 18.07.2018

УДК $271.4-725(477)(092)$

DOI:

Олег Кекош, кандидат педагогічних наук, викладач кафедри культурологї̈ та украӥнознавства Дрогобицького державного педагогічного університету імені Івана Франка

\section{ХРИСТИЯНСЬКА ПЕДАГОГІКА ВИХОВАННЯ ДІТЕЙ ТА МОЛОДІ У ПРОСВІТНИЦЬКІЙ ДІЯЛЬНОСТІ АНДРЕЯ ШЕПТИЦЬКОГО}

Досліджено головні ідеї просвітнииької діяльності митрополита Андрея Шептииького та обтрунтовано їх актуальність у діяльності сучасних душпастирів. Застосовано синтетично-аналітичний метод і розкрито методологію виховання у творах митрополита Андрея Шептицького. Проаналізовано актуальні питання виховання дітей та молоді на основі християнських иінностей. Запропоновано ідеї, які сприятимуть подоланню стереотипів педагогічного мислення, творчому використанню історичного вітчизняного освітнього досвіду в сучасних умовах перебудови українського шкільниитва, зокрема, у вирішенні окремих сочіальних проблем й організації позаурочної та позашкільної виховної роботи в середніх школах, спрямованої на моральне виховання учнів.

Ключові слова: Андрей Шептииький; християнське виховання; иінності виховання; українська школа; діти; молодь

Лim. 9.

Oleh Kekosh, Ph.D.(Pedagogy), Lecturer of Cultural Etudies and Study of Ukraine Department Drohobych Ivan Franko State Pedagogical University

\section{CHRISTIAN PEDAGOGY OF THE UPBRINGING OF CHILDREN AND YOUTH IN THE EDUCATIONALACTIVITY OF ANDREY SHEPTYTSKIY}

In the article the main educational ideas of Metropolitan Andrey Sheptytskiy are explored. The purpose of the article is to research the influence of Christian pedagogy on moral education of children and youth. The current state of education is characterized by an active search for the ways of improving the effectiveness of the process of moral and patriotic education at school. Nowadays the study of historical pedagogical heritage has become one of the priority directions in the implementation of patriotic education in our country, which is reflected in the introduction of Christian values into the educational process at school. The main forms of Sheptytskiy's educational activity are explored. The ideas of Metropolitan Andrey concerning the Christian education of children and youth are characterized and their significance in modern educational reality is shown. The moral and pastoral messages of Metropolitan Andrey Sheptytskiy are analysed and the ideals of Christian education are offered for children and youth.

A variety of methods of moral and patriotic education for all participants of the educational process at school are presented. The importance of school and family partnership in education is described. Mutual work of church and school contributes to the success of pupils, prevents problems, resolves misunderstandings that arise in the process of moral education. The educational and cultural activity of Metropolitan Andrey Sheptytskiy has been 